\title{
Metals and Minerals as a Biotechnology Feedstock: Engineering Biomining Microbiology for Bioenergy Applications
}

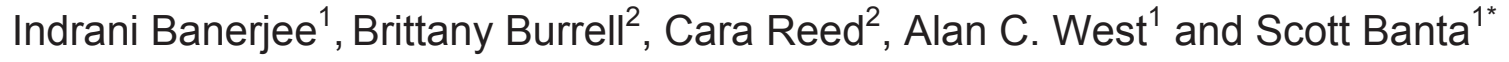 \\ ${ }^{1}$ Department of Chemical Engineering, Columbia University, 500 W. $120^{\text {th }}$ Street, New \\ York, NY 10027, USA. \\ ${ }^{2}$ Technology Center, Freeport-McMoRan, 9780 E. Sanchez Road, Safford, AZ 85546, \\ USA.
}

*Corresponding Author: Scott Banta, sbanta@columbia.edu

\section{Abstract}

Developing new feedstocks for the efficient production of biochemicals and biofuels will be a critical challenge as we diversify away from petrochemicals. One possible opportunity is the utilization of sulfide-based minerals in the Earth's crust. Nonphotosynthetic chemolithoautotrophic bacteria are starting to be developed to produce biochemicals from $\mathrm{CO}_{2}$ using energy obtained from the oxidation of inorganic feedstocks. Biomining of metals like gold and copper already exploit the native metabolism of these bacteria and these represent perhaps the largest-scale bioprocesses ever developed. The metabolic engineering of these bacteria could be a desirable alternative to classical heterotrophic bioproduction. In this review, we discuss biomining operations and the challenges and advances in the engineering of associated 
chemolithoautotrophic bacteria for biofuel production. The co-generation of biofuels integrated with mining operations is a largely unexplored opportunity that will require advances in fundamental microbiology and the development of new genetic tools and techniques for these organisms. Although this approach is presently in its infancy, the production of biochemicals using energy from non-petroleum mineral resources is an exciting new biotechnology opportunity. 


\section{Introduction}

The development of technologies for recycling $\mathrm{CO}_{2}$ to create biofuels and biochemicals is a grand engineering challenge. Initial approaches have relied on photosynthesis to capture $\mathrm{CO}_{2}$ and use photonic energy to generate chemical bonds which are then processed into biofuels directly or through heterotrophic bioprocessing. While plants and photosynthetic microorganisms are very good at capturing and using $\mathrm{CO}_{2}$, the overall energy efficiency of photosynthesis is poor [1] and this approach competes with agriculture [2]. Ethanol is a first generation biofuel initially generated from food crops such as corn or sugarcane, and production of ethanol is moving towards exploiting cellulose as a feedstock. Non-photosynthetic autotrophic bacteria have also been explored for the fixation of $\mathrm{CO}_{2}$ and the generation of useful chemicals and fuels $[1,3,4]$. Butanol is a second generation biofuel with a higher energy density and can be produced autotrophically by engineered bacteria [1,3-6].

Chemolithoautotrophs have evolved to oxidize inorganic materials and some of these bacteria, such as Acidithiobacillus spp. and Leptospirillum spp., are exploited in metal mining operations for increased leaching rates of metals from ores [7-9]. Given that the dimensions of a bioleaching heap can be as large as one trillion liters, it is thought that metal biomining with chemolithoautotrophic bacteria represents the largest-scale bioprocess ever developed [10]. These processes rely on native microbial consortia, but reports on the engineering of these cells are beginning to emerge [11-23]. Future work aimed at the metabolic engineering of these cells for co-generation of useful chemicals and fuels using atmospheric $\mathrm{CO}_{2}$ and the energy available in metal sulfide feedstocks could represent a new paradigm in bioproduction. Currently, the globally 
identified sulfur resources amount to approximately 5 billion tons [24] which can release up to $10^{14} \mathrm{MJ}$ of energy during oxidation. These resources include elemental sulfur found in evaporite and volcanic deposits in addition to sulfur associated with natural gas, petroleum, tar sands, and metal sulfides [24]. The energy released during oxidation of sulfur [25] is comparable to other energy related materials such as petroleum and glucose $[26,27]$ (Figure 1). This review describes the current state of biomining operations involving sulfide based feedstocks as well as recent advances in the genetic engineering of chemolithoautotrophic and related biomining bacteria with a focus on biochemical generation.

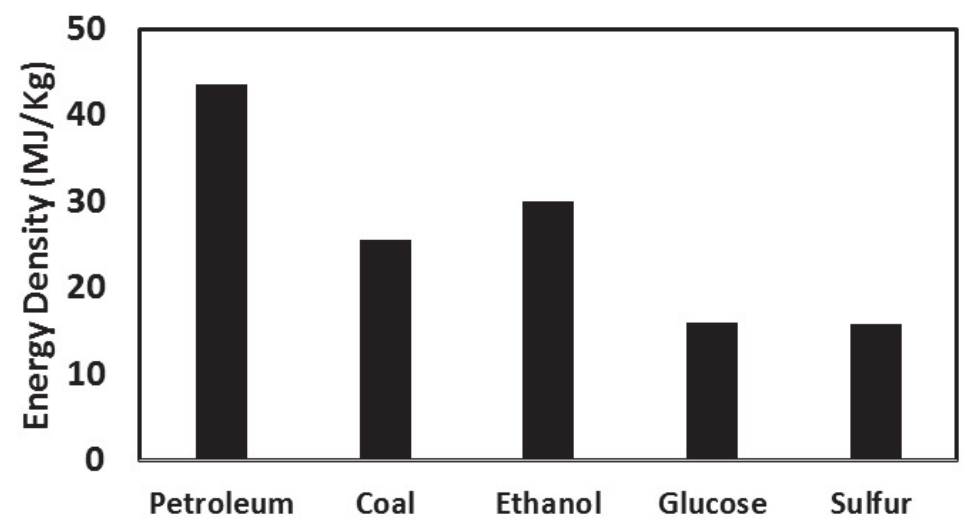

Figure 1. A comparison of energy densities from complete oxidation of petroleum, coal, ethanol, glucose and sulfur [25-27]. Although petroleum has a greater energy density than sulfur, metal sulfides are as abundant as petroleum and could represent an untapped feedstock for the production of biochemicals and biofuels.

\section{Current Biomining Operations}


Although the role of microorganisms in metal mining processes were undiscovered until approximately 70 years ago, it is likely these microbes have been contributing to the recovery of metals from ores for hundreds of years $[7,28]$. Biotechnological methods for recovery of metals are becoming increasingly important to current industrial applications. Copper and gold biomining practices are well-developed and accepted; in that globally, approximately $5 \%$ of gold, $15 \%$ of copper, and lesser percentages of the other base metals, are presently leached through the deliberate use of microorganisms [29]. Table 1 lists some examples of biomining operations that focus on bioleaching of metals or biooxidation of minerals for metal extractions.

Table 1. Bioleaching and Biooxidation Operations

\begin{tabular}{|c|c|}
\hline Location & Company \\
\hline \multicolumn{2}{|c|}{ Copper } \\
\hline Morenci, Arizona & Freeport-McMoRan \\
\hline Girilambone, Australia & Straits Resources \& Nord Pacific \\
\hline Lady Annie, Australia & NetMind Financial Holdings Ltd \\
\hline Mount Gordon, Australia & Lighthouse Minerals and EMR Capital \\
\hline Mt Leyshon, Australia & Formerly Normandy Poseidon \\
\hline Birla Nifty, Australia & Adity Birla \\
\hline Whim Creek/Mons Cupri, Australia & Venturex Resources Ltd \\
\hline Andacollo Cobre, Chile & Teck Resources \\
\hline El Abra, Chile & Freeport-McMoRan \\
\hline Escondida, Chile & BHP Billiton \\
\hline Chuquicamata, Chile & Codelco \\
\hline Cerro Colorado, Chile & BHP Billiton \\
\hline Dos Amigos, Chile & CEMIN \\
\hline El Abra, Chile & Freeport-McMoRan \\
\hline Ivan-Zar, Chile & Compania Minera Milpro \\
\hline Lince II, Chile & Antofagasta Plc \\
\hline Lo Aguirre, Chile & Sociedad Minera Pudahuel \\
\hline Lomas Bayas, Chile & Xstrata \\
\hline Punta del Cobre, Chile & Sociedad Punta del Cobre \\
\hline Quebrada Blanca, Chile & Teck Resources \\
\hline Radomiro Tomic, Chile & Codelco \\
\hline Spence, Chile & BHP Billiton \\
\hline Tres Valles, Chile & Vecchiola Group \\
\hline Zaldivar, Chile & Barrick Gold \\
\hline Zijinshan Copper, China & Zijin Mining Group Co., Ltd \\
\hline Skouriotissa Copper, Cyprus & Cyprus Mines Corporation \\
\hline Monywa, Myanmar & Myanmar No.1 Mining Enterprise \\
\hline
\end{tabular}




\begin{tabular}{cc} 
Cerro Verde, Peru & Freeport McMoRan \\
Lisbon Valley, Utah & Lisbon Valley Mining Company \\
Jinchuan Copper, China & Zijin Mining Group \\
Skouriotissa Copper, Cyprus & Hellenic Copper \\
Cajamarca, Peru & Newmont Mining \\
Sotkamo, Finland & Talvivaara \\
Kasese town, Uganda & Kosese Cobalt Company Ltd \\
\hline & \\
\hline Fairview, Barberton, South Africa & Pan African Resources \\
Sao Bento Brazil & AngloGold Ashanti \\
Wiluna, Australia & Apex Minerals \\
Ashanti, Obuasi, Ghana & AngloGold Ashanti \\
Youanmi, Australia & Apex Minerals \\
Ramboraque, San Mateo, Peru & Gold Hawk Resources \\
Beaconsfield, Tasmania, Australia & Beaconsfield Gold \\
Laizhou, Shandong Province, China & Eldorado Gold \\
Suzdal, Kazakhstan & Centroserve \\
Fosterville, Victoria, Australia & Northgate Minerals \\
Bogoso, Ghana & Golden Star Resources \\
Jinfeng, Chinga & Eldorado Gold \\
Kokpatas, Uzbekistan & Navoi Mining and Metallurgy \\
\hline Sotkamo, Finland & \\
\hline Adapted from [29] with modifications. & Talvivaara Mining Plc \\
\hline
\end{tabular}

Other metals, such as uranium, lead, manganese, and cobalt, have also been proven to be successfully biomined. Worldwide, there are over forty industrial plants targeting recovery of these various metals through bioleaching [30]. Additionally, although the process has not been proven on a large scale, there is promise for bioleaching of molybdenum [31]. Processing of waste streams is also becoming increasingly valuable through biomining. The metals in these materials were previously deemed uneconomical by non-biological methods. For example, today's copper tailings still contain about $0.1 \%$ weight copper; while older tailings, due to the inefficiency of prior processes, contain between 0.2 to $0.6 \%$ weight copper [32].

The large-scale engineering approaches to bioleaching or biooxidation in commercial applications include dump leaching, heap leaching, and continuous stirred tank 
leaching. Another method, although not as commonly practiced in the present day, is in situ leaching. Dump bioleaching was first applied on an industrial scale around the mid1900s [8]. This process is more predominant in the mining industry for bioleaching of copper. Dump leaching allows leaching of low-grade ores that cannot be economically processed by typical methods used to produce copper concentrate. These dumps are constructed by placing blasted below cut-off grade ore (anything below $0.6 \%$ wt. $\mathrm{Cu}$ [32]) on pads where it is treated with an acidic solution. This material is typically referred to as run-of-mine ore (ROM). Autotrophic microorganisms that are native to the environment catalyze the leaching process and become more prevalent as the conditions become more acidic and favorable for organism growth.

Although similar to dump bioleaching, heap bioleaching involves more planning and a greater depth of engineering in efforts to optimize the leaching conditions (Figure 2). Additional measures are taken in preparing the ore prior to stacking on a heap. Once the ore is blasted, it is crushed down to a smaller size. Crushing ore is dependent on ore grade, higher grade ore is crushed to a predetermined particle size. The ore is then conditioned by agglomeration, allowing finer particles to attach. Some operations condition the ore with indigenous microbes. Once the ore is conditioned, it is conveyed to specifically designed pads and stacked in lifts. Due to the oxidative conditions required for most metal dissolution reactions, these engineered heaps are aerated with external blowers. Forced air is a fairly common practice and is also important for the cultivation of microbes within the heap. Raffinate, a weak acidic solution, is applied and percolates throughout the heap. The leachate solution that is collected at the bottom of heaps, is typically processed through solvent extraction/electrowinning (SX/EW) 
technologies. Designed organic solvent extractants are used to release the metal of interest from the host solution under vigorous mixing. After a series of settling and mixing procedures, a highly concentrated solution of the desired metal is routed to the final step, electrowinning (EW). A metal anode sheet is placed in a cell with the high metal containing solution and a high voltage is applied to the cell. The metal ions adhere to the anode metal sheet, creating a cathode of the leached metal. This process is detrimental to the survival of microbes within the leachate. It is estimated that there is an approximate loss of $10^{2}$ cells per milliliter throughout the solvent extraction process. However, once the recycled solution is reapplied to the heap, the microbial population increases over time to approximately $10^{4}-10^{6}$ microbes per gram of ore [33].

Heap bioleaching has more recently been applied as a pre-treatment process in leaching gold ores. This technology is particularly used to oxidize sulfide minerals that are later treated with reagents in order to recover the gold [34]. Stirred tank reactors are another engineering application used in biomining. The tanks operate at moderate temperatures, typically constructed out of stainless steel, aerated, and agitated in order to keep the concentrate suspended. Driven by operational costs, this technology is typically used to biooxidize or bioleach mineral concentrates [34]. A final example of industrial biomining applications is in situ bioleaching. This method consists of leaching ore in its natural location, without excavation. A solution is pumped through passages that have been drilled within the ore, the leachate is collected and then processed for the recovery of metals.

There is also some headway in the bioprocessing of certain ores under reducing conditions, such as with lateritic materials [28]. Nickel and cobalt are examples of 
metals that can be extracted under reducing conditions, unlike the oxidizing conditions used to biomine copper and gold. Development of bioleaching processes is the key to recovering the metals in increasingly abundant low-grade ores. Bioleaching methods are less energy intensive, environmentally considerate, and have the potential to generate by-products that can be of value to other processes within the mine. For these reasons alone, new biotechnological advancements within biomining will likely have a tremendous impact in future metal recovery efforts.

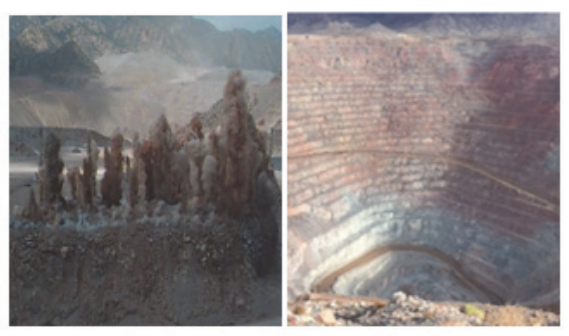

1. Blasting, loading, and hauling<smiles>C1CCCC1</smiles>

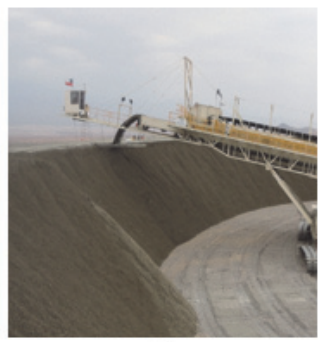

2. Stacking ore

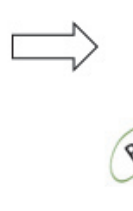

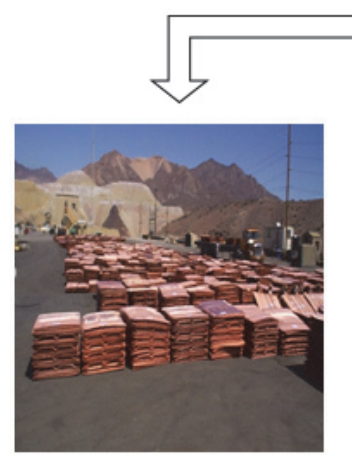

6. Final cathodes

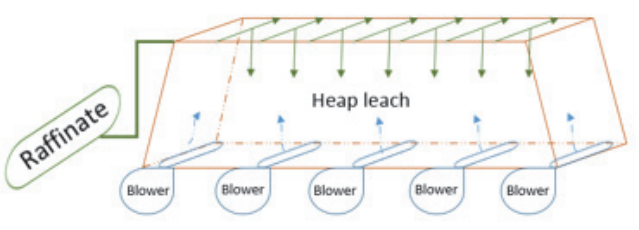

3. Schematic of a heap
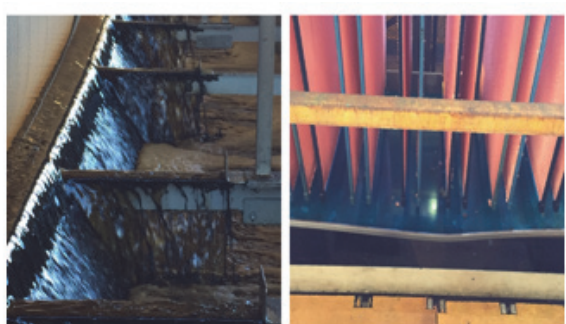

5. Solvent extraction and electrowinning
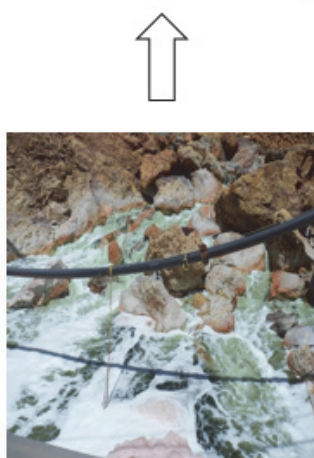

4. Leachate reporting 


\begin{tabular}{|c|c|}
\hline Examples of mineral reactions without microbes & Examples of mineral reactions with microbes \\
\hline $\begin{array}{l}\text { Pyrite } \\
\qquad \mathrm{FeS}_{2}+6 \mathrm{Fe}^{3+}+3 \mathrm{H}_{2} \mathrm{O} \rightarrow \mathrm{S}_{2} \mathrm{O}_{3}^{2-}+7 \mathrm{Fe}^{2+}+6 \mathrm{H}^{+}\end{array}$ & $\begin{array}{l}\text { Pyrite } \\
\begin{array}{l}\mathrm{FeS}_{2}+6 \mathrm{Fe}^{3+}+3 \mathrm{H}_{2} \mathrm{O} \rightarrow \mathrm{SO}_{4}^{2-}+7 \mathrm{Fe}^{2+}+6 \mathrm{H}^{+} \\
2 \mathrm{Fe}^{2+}+\frac{1}{2} \mathrm{O}_{2}+2 \mathrm{H}^{+} \rightarrow 2 \mathrm{Fe}^{3+}+\mathrm{H}_{2} \mathrm{O}\end{array}\end{array}$ \\
\hline $\begin{array}{l}\text { Sphalerite } \\
\begin{array}{l}\mathrm{ZnS}+\mathrm{Fe}^{3+}+\mathrm{H}^{+} \rightarrow \mathrm{Zn}^{2+}+0.5 \mathrm{H}_{2} \mathrm{~S}_{n}+\mathrm{Fe}^{2+}(n \geq 2) \\
\mathrm{H}_{2} \mathrm{~S}_{n}+2 \mathrm{Fe}^{3+} \rightarrow 0.25 \mathrm{~S}_{8}+2 \mathrm{Fe}^{2+}+2 \mathrm{H}^{+}\end{array}\end{array}$ & $\begin{array}{l}\text { Sphalerite } \\
\qquad \begin{array}{l}\mathrm{ZnS}+\mathrm{Fe}^{3+}+\mathrm{H}^{+} \rightarrow \mathrm{Zn}^{2+}+0.5 \mathrm{H}_{2} \mathrm{~S}_{n \geq 2}+\mathrm{Fe}^{2+} \\
\mathrm{H}_{2} \mathrm{~S}_{n}+2 \mathrm{Fe}^{3+} \rightarrow 0.25 \mathrm{~S}_{8}+2 \mathrm{Fe}^{2+}+2 \mathrm{H}^{+} \\
0.5 \mathrm{~S}_{8}+3 \mathrm{O}_{2}+2 \mathrm{H}_{2} \mathrm{O} \rightarrow 2 \mathrm{SO}_{4}^{2-}+4 \mathrm{H}^{+}\end{array}\end{array}$ \\
\hline
\end{tabular}

Figure 2. Schematic of heap bioleaching, which is a common biomining practice, and the reactions involved for the recovery of copper along with other metals. Top Panel 1: Ore is drilled in an arranged pattern and then blasted (left). An open pit is created with benches around $50 \mathrm{ft}$. high (right). Ore is then transferred to either a heap or crusher. 2: A conveyor system stacks the ore.3: Specially designed heaps are constructed for various ore grades, particle sizes, flow rates, air injections, and multiple other factors. A weak acid solution is irrigated from the top and percolates throughout the heap. 4: Leachate solution reports from the bottom of the heap and routed to collection ponds. 5 : A solvent extraction (SX) circuit is used to release the metal of interest from the host solution (left). Solution is sent to the electrowinning (EW) area where a metal cathode is produced (right). 6: Cathode sheets are then sent to customers or rod mills. Bottom Panel Heap leaching reactions - Left: Two examples of chemical reactions that are found in heap leaching without microbe reactions. Pyrite, a non-metal mineral, once oxidized, is a source of ferric iron $\left(\mathrm{Fe}^{3+}\right)$ and sulfuric acid $\left(\mathrm{H}_{2} \mathrm{SO}_{4}\right)$. Without microbes, the reaction stalls after the initial reaction (1). Sphalerite is a metal containing mineral and relies on the presence of ferric iron for metal liberation (2). The products of reaction (3) are left with elemental sulfur and ferrous iron $\left(\mathrm{Fe}^{2+}\right)$ which, are not further utilized without microbial interaction. Right: When microbes are present, the product of the 
initial reaction can become the reactants. Ferrous iron, a product of the initial reaction, can be oxidized back to ferric iron through microbial metabolisms (4). Elemental sulfur can be further oxidized to sulfuric acid (5). Thus, the reactions by microbes act as catalysts to the initial (1), (2), and (3) reactions.

\section{Abundance of Reduced Material in the Earth's Crust}

There are no known global shortages of mineral resources, and the demand for these resources will continue to grow, requiring continued efforts in development and exploration $[35,36]$. Thus the processing of energy rich sulfide streams will continue to accelerate. According to the United States Geological Survey, upwards of 70 chemical elements and dozens of minerals are mined from over 100 different deposit types and geologic surroundings [35].

Metal sulfides, tar sands, petroleum, natural gas, and elemental sulfur resources in evaporite and volcanic deposits make up approximately 5 billion tons of Earth's sulfur [24]. Most sulfur production is a result of fossil-fuel related processes, where opportunities for improvement in sustainability and supply are abundant. Sulfur reserves in sulfide ores are large, with one of the largest physical reservoirs in the Earth's crust being found in pyrite $\left(\mathrm{FeS}_{2}\right)$. Metal sulfides make up the majority of the world supplies of non-ferrous metals and can be considered to be a key group of ore minerals [37]. The metals most commonly found in sulfide minerals includes copper, cobalt, iron, lead, nickel, silver, and zinc. Metal concentration contained in sulfide ores is relatively low, typically less than a few percent [37]. These sulfide minerals can undergo biological oxidation under both aerobic and anaerobic conditions. When oxygen is present, the 
oxidation of sulfur produces sulfuric acid. Elemental sulfur generates $530 \mathrm{~kJ}$ of heat per mole of sulfur oxidized. This energy, which is typically released as heat, can be exploited [38].

Mining companies worldwide are faced with depleting oxide ore bodies and are tasked with finding ways to tap into the deeper, more complex, sulfide ores [34]. A primary copper sulfide, chalcopyrite, accounts for $70 \%$ of the world's copper reserves $[39,40]$. As of 2016 the world's total copper reserves have been estimated to contain about 5 billion metric tons of copper [24]. Considering 70\% of this copper is from chalcopyrite, which contains about $35 \%$ by weight of sulfur, the amount of sulfur from chalcopyrite can be calculated to be around 3.5 billion metric tons which when oxidized (energy of oxidation of elemental sulfur being $530 \mathrm{KJ} / \mathrm{mole}$ ) can release energy in the order of $10^{13}$ MJ. However, chalcopyrite is a refractory copper containing mineral that poses many challenges for effective leaching, such as a proposed passivation layer that renders the mineral insoluble [41]. These types of deposits, as well as below cut-off grade material for copper [32] are becoming targets for processing. Table 2 lists these types of sulfide minerals.

The most abundant minerals for biooxidation include pyrite, pyrrhotite, galena, sphalerite, chalcopyrite, and chalcocite [37]. Mechanisms for the microbial oxidation of sulfide materials are shown in Figure 3 [42]. Metal bearing minerals such as arsenopyrite and chalcocite generate heats of reaction of $-9,415 \mathrm{~kJ} / \mathrm{kg}$ and $-8,201 \mathrm{~kJ} / \mathrm{kg}$, respectively. Whereas, pyrite and pyrrhotite, minerals that do not harbor metals desirable for mining, generate heats of reaction of $-12,884 \mathrm{~kJ} / \mathrm{kg}$ and $-11,373 \mathrm{~kJ} / \mathrm{kg}$ [33].

Table 2. List of common types of sulfide minerals. 


\begin{tabular}{cc}
\hline Mineral & Formula \\
\hline Ferrous Containing \\
\hline Arsenopyrite & $\mathrm{FeAsS}$ \\
Bornite & $\mathrm{Cu} 5 \mathrm{Fe} S 4$ \\
Chalcopyrite & $\mathrm{CuFeS2}$ \\
Pyrite & $\mathrm{FeS} 2$ \\
Pyrrhotite & $\mathrm{Fe} 7 \mathrm{~S} 8$ \\
\hline Non-Ferrous Containing \\
\hline Argentite & $\mathrm{Ag} 2 S$ \\
Chalcocite & $\mathrm{Cu} 2 \mathrm{~S}$ \\
Covellite & $\mathrm{CuS}$ \\
Digenite & $\mathrm{Cu} 9 S 5$ \\
Galena & $\mathrm{PbS}$ \\
Millerite & $\mathrm{NiS}$ \\
Molybdenite & $\mathrm{MoS} 2$ \\
Orpiment & $\mathrm{As} 2 S 3$ \\
Sphalerite & $\mathrm{ZnS}$ \\
\hline
\end{tabular}
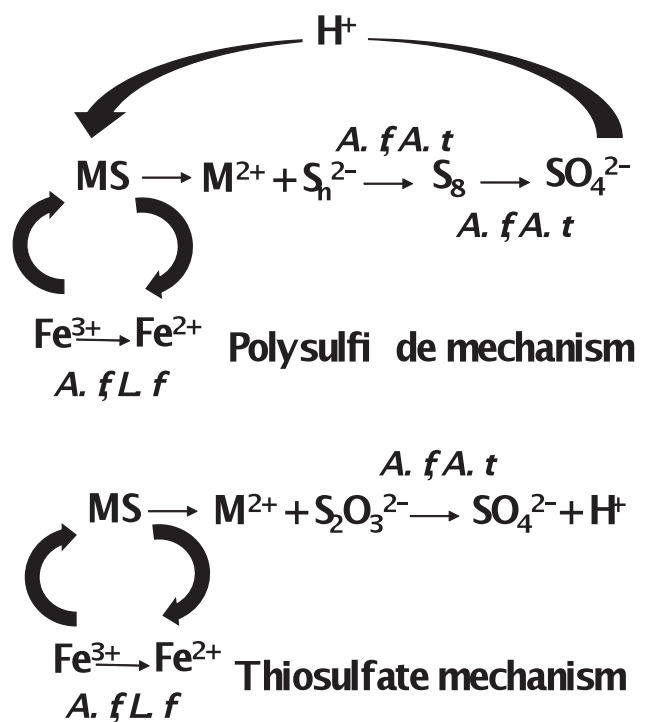

Figure 3. Schematic of two different mechanisms of mesoacidophilic bioleaching showing the intermediate sulfur compounds formed. A.f, A.t and L.f stand for Acidithiobacillus ferrooxidans, Acidithiobacillus thiooxidans, Leptospirillum ferriphilium bacteria respectively [42]. 
These minerals are also prime pathways for the conversion of ferrous (Fe(II)) to ferric $(\mathrm{Fe}(\mathrm{III}))$ iron, which not only liberates the desired metal from its host mineral, but is exothermic, increasing the temperature and the leach rate of metal-containing minerals. Along with the aforementioned pyrite and pyrrhotite minerals, arsenopyrite, chalcocite, and chalcopyrite also generate energy during oxidation, with an average heat of reaction of $-9,069 \mathrm{~kJ} / \mathrm{kg}$ of mineral. Heap leaching systems are currently in place that target the oxidation of pyrite ores, specifically for heat generation [43]. However, no efforts have been made to date to capture this energy to drive chemical bioproduction.

\section{Microbiology in Mining Operations}

The predominant microorganisms related to mining operations share some unique physiological characteristics: most are acidophilic $(\mathrm{pH} 1-3)$, have high metal ion resistance, are chemolithoautotrophic deriving carbon from $\mathrm{CO}_{2}$, and derive energy from the oxidation of ferrous or reduced inorganic sulfur compounds (RISCs). The fixation of $\mathrm{CO}_{2}$ in some of the chemolithoautotrophs including Acidothiobacillus is through the Calvin-Benson-Bassham pathway [3] which involves $\mathrm{CO}_{2}$ capture using ribulose bisphosphate carboxylase/oxygenase (RubisCo). Two structurally distinct forms of RubisCo (I and II), with different catalytic properties, are typically present in autotrophs and genes encoding both these forms has been found in $A$. ferrooxidans [10]. Other carbon fixation pathways identified in chemolithoautotrophs include the Wood-Ljungdahl pathway, the 3-hydroxy- propionate bicycle, the reductive tricarboxylic 
acid cycle, 3-hydroxypropionate-4-hydroxy-butyrate cycle and 3-hydroxypropionate-4hydroxy-butyrate cycle $[3,44]$.

The optimal growth temperatures for these microorganisms vary considerably, such that mesophilic to extremely thermophilic microorganisms are involved. Various obligate acidophilic microbes, which naturally occur in mining environments, are listed in Table 3. Even though some of these microbes occur more frequently than the others, a naturally occurring microbial consortia is generally responsible for bioleaching and recovery of metals during mining [45].

The key mesoacidophilic microorganisms involved in biomining are Acidithiobacillus ferrooxidans, Acidithiobacillus thiooxidans, Leptospirillum ferrooxidans and Leptospirillum ferriphilum. Metal sulfide oxidation involved in heap bioleaching is exothermic, thus encouraging the growth of the thermoacidophiles. Acidithiobacillus caldus is common at moderately high temperatures $\left(40-45^{\circ} \mathrm{C}\right)$ while species from the genera Metallosphaera, Sulfolobus and Acidianus are considered to be the most important at temperatures higher than $60{ }^{\circ} \mathrm{C}[9,46]$.

Most of the biomining microorganisms derive energy from the oxidation of soluble ferrous or RISCs (summarized in Table 3) and generate ferric ions and sulfuric acid creating favorable conditions for bioleaching [47]. Most of these microorganisms are either iron oxidizers like L. ferrooxidans and L. ferriphilum or sulfur oxidizers like $A$. thiooxidans and $A$. caldus with the exception of $A$. ferrooxidans, which can oxidize both iron and sulfur.

Table 3. List of naturally occurring microbes within mining environments. 


\begin{tabular}{|c|c|c|c|c|c|c|c|c|}
\hline \multirow[t]{2}{*}{ Species } & \multirow[t]{2}{*}{ Metabolism } & \multicolumn{3}{|c|}{ Oxidize } & \multirow{2}{*}{$\begin{array}{c}\begin{array}{c}\text { Reduc } \\
\mathrm{e}\end{array} \\
\mathrm{Fe}^{3+}\end{array}$} & \multirow{2}{*}{$\begin{array}{l}\text { Growth } \\
\text { Range } \\
\left({ }^{\circ} \mathrm{C}\right)\end{array}$} & \multirow{2}{*}{$\begin{array}{c}\text { Mode of } \\
\text { Respiratio } \\
n\end{array}$} & \multirow{2}{*}{$\begin{array}{c}\text { Genome } \\
\text { Assembl } \\
\text { y Level }\end{array}$} \\
\hline & & $\mathrm{Fe}_{+}^{2}$ & $S^{\circ}$ & $\begin{array}{c}\text { RIS } \\
C^{i}\end{array}$ & & & & \\
\hline $\begin{array}{l}\text { Acidiferrobacter } \\
\text { thiooxydans }\end{array}$ & $\begin{array}{l}\text { Chemolithoautotrop } \\
\mathrm{h}^{\mathrm{a}} \\
\text { Diazotroph }^{\mathrm{b}}\end{array}$ & $\begin{array}{l}\text { Ye } \\
s\end{array}$ & $\begin{array}{l}\text { Ye } \\
s\end{array}$ & Yes & Yes & $38-47$ & $\begin{array}{l}\text { Facultativ } \\
\text { e } \\
\text { anaerobe }\end{array}$ & Contig \\
\hline $\begin{array}{l}\text { Acidimicrobium } \\
\text { ferrooxidans }\end{array}$ & Mixotroph $^{c}$ & $\begin{array}{l}\text { Ye } \\
\mathrm{s}\end{array}$ & No & No & No & $45-50$ & Aerobe & Complete \\
\hline $\begin{array}{l}\text { Acidiphilium } \\
\text { acidophilum }\end{array}$ & $\begin{array}{l}\text { Mixotroph } \\
\text { DIRB }^{\mathrm{d}}\end{array}$ & No & $\begin{array}{l}\mathrm{Ye} \\
\mathrm{s}\end{array}$ & Yes & Yes & $10-35$ & Aerobe & $\mathrm{N} / \mathrm{A}$ \\
\hline $\begin{array}{l}\text { Acidiphilium } \\
\text { angustum }\end{array}$ & Heterotroph $^{e}$ & No & No & No & No & $20-42$ & Aerobe & Scaffold \\
\hline $\begin{array}{l}\text { Acidiphilium } \\
\text { cryptum }\end{array}$ & $\begin{array}{l}\text { Heterotroph } \\
\text { DIRB }^{\mathrm{e}}\end{array}$ & No & No & No & Yes & $20-41$ & Aerobe & Complete \\
\hline $\begin{array}{l}\text { Acidiphilium } \\
\text { iwatense }\end{array}$ & Chemoorganotroph $^{f}$ & No & No & No & No & $22-35$ & Aerobe & $\mathrm{N} / \mathrm{A}$ \\
\hline $\begin{array}{l}\text { Acidiphilium } \\
\text { multivorum }\end{array}$ & Chemoorganotroph $^{f}$ & No & No & No & No & $17-42$ & Aerobe & Complete \\
\hline $\begin{array}{l}\text { Acidiphilium } \\
\text { organovorum }\end{array}$ & $\begin{array}{l}\text { Heterotroph } \\
\text { DIRB }^{\mathrm{d}}\end{array}$ & No & No & No & Yes & $30-42$ & Aerobe & $\mathrm{N} / \mathrm{A}$ \\
\hline $\begin{array}{l}\text { Acidiphilium } \\
\text { rubrum }\end{array}$ & $\begin{array}{l}\text { Heterotroph } \\
\text { AAPB }^{\mathrm{g}^{*}}(\mathrm{Zn}-\mathrm{BChl} a)\end{array}$ & No & No & No & No & $20-42$ & $\begin{array}{l}\text { Facultativ } \\
\text { e } \\
\text { anaerobe }\end{array}$ & Contig \\
\hline $\begin{array}{l}\text { Acidiphilium } \\
\text { symbioticum }\end{array}$ & Heterotroph $^{\mathrm{e}}$ & No & No & No & No & $30-37$ & Aerobe & $\mathrm{N} / \mathrm{A}$ \\
\hline $\begin{array}{l}\text { Acidithiobacillus } \\
\text { albertensis }\end{array}$ & $\begin{array}{l}\text { Chemolithoautotrop } \\
\mathrm{h}^{\mathrm{a}}\end{array}$ & No & $\begin{array}{l}\text { Ye } \\
\mathrm{s}\end{array}$ & Yes & No & $25-30$ & Aerobe & $\mathrm{N} / \mathrm{A}$ \\
\hline $\begin{array}{l}\text { Acidithiobacillus } \\
\text { caldus }\end{array}$ & Mixotroph $^{c}$ & No & $\begin{array}{l}\text { Ye } \\
\mathrm{s}\end{array}$ & Yes & No & $32-52$ & Aerobe & Complete \\
\hline $\begin{array}{l}\text { Acidithiobacillus } \\
\text { ferrivorans }\end{array}$ & $\begin{array}{l}\text { Chemolithoautotrop } \\
\mathrm{h}^{\mathrm{a}} \\
\text { Diazotroph }^{\mathrm{b}}\end{array}$ & $\begin{array}{l}\text { Ye } \\
\mathrm{s}\end{array}$ & $\begin{array}{l}\text { Ye } \\
\mathrm{s}\end{array}$ & Yes & Yes & $4-37$ & $\begin{array}{l}\text { Facultativ } \\
\text { e } \\
\text { anaerobe }\end{array}$ & Complete \\
\hline $\begin{array}{l}\text { Acidithiobacillus } \\
\text { ferridurans }\end{array}$ & $\begin{array}{l}\text { Chemolithoautotrop } \\
\mathrm{h}^{\mathrm{a}}\end{array}$ & $\begin{array}{l}\text { Ye } \\
\mathrm{s}\end{array}$ & $\begin{array}{l}\text { Ye } \\
\mathrm{s}\end{array}$ & Yes & Yes & $10-37$ & $\begin{array}{l}\text { Facultativ } \\
\mathrm{e} \\
\text { anaerobe }\end{array}$ & $\mathrm{N} / \mathrm{A}$ \\
\hline $\begin{array}{l}\text { Acidithiobacillus } \\
\text { ferrooxidans }\end{array}$ & $\begin{array}{l}\text { Chemolithoautotrop } \\
\mathrm{h}^{\mathrm{a}} \\
\text { Diazotroph }^{\mathrm{b}}\end{array}$ & $\begin{array}{l}\text { Ye } \\
\mathrm{s}\end{array}$ & $\begin{array}{l}\text { Ye } \\
\mathrm{s}\end{array}$ & Yes & Yes & $10-37$ & $\begin{array}{l}\text { Facultativ } \\
\text { e } \\
\text { anaerobe }\end{array}$ & Complete \\
\hline $\begin{array}{l}\text { Acidithiobacillus } \\
\text { thiooxidans }\end{array}$ & $\begin{array}{l}\text { Chemolithoautotrop } \\
\mathrm{h}^{\mathrm{a}}\end{array}$ & No & $\begin{array}{l}\text { Ye } \\
s\end{array}$ & Yes & No & $18-37$ & Aerobe & Contig \\
\hline $\begin{array}{l}\text { Acidithrix } \\
\text { ferrooxidans }\end{array}$ & $\begin{array}{l}\text { Heterotroph } \\
\text { DIRB }^{\mathrm{e}}\end{array}$ & $\begin{array}{l}\text { Ye } \\
\mathrm{s}\end{array}$ & No & No & Yes & $10-30$ & $\begin{array}{l}\text { Facultativ } \\
\text { e } \\
\text { anaerobe }\end{array}$ & Contig \\
\hline $\begin{array}{l}\text { Acidobacterium } \\
\text { capsulatum }\end{array}$ & Chemoorganotroph $^{f}$ & No & No & No & No & $25-37$ & Aerobe & Complete \\
\hline Acidocella facilis & Chemoorganotroph $^{f}$ & No & No & No & No & $25-37$ & Aerobe & Contig \\
\hline $\begin{array}{l}\text { Alicyclobacillus } \\
\text { disulfidooxidans }\end{array}$ & Mixotroph $^{c}$ & $\begin{array}{l}\text { Ye } \\
s\end{array}$ & $\begin{array}{l}\text { Ye } \\
\mathrm{s}\end{array}$ & Yes & No & $4-40$ & Aerobe & N/A \\
\hline $\begin{array}{l}\text { Alicyclobacillus } \\
\text { tolerans }\end{array}$ & Mixotroph $^{\mathrm{C}}$ & $\begin{array}{l}\text { Ye } \\
\mathrm{s}\end{array}$ & $\begin{array}{l}\text { Ye } \\
\mathrm{s}\end{array}$ & No & Yes & $20-55$ & Aerobe & Scaffold \\
\hline $\begin{array}{l}\text { Ferrimicrobium } \\
\text { acidiphilum }\end{array}$ & Heterotroph $^{\mathrm{e}}$ & $\begin{array}{l}\text { Ye } \\
\mathrm{s}\end{array}$ & No & No & Yes & $30-37$ & $\begin{array}{l}\text { Facultativ } \\
\text { e } \\
\text { anaerobe }\end{array}$ & Scaffold \\
\hline $\begin{array}{l}\text { Ferrithrix } \\
\text { thermotolerans }\end{array}$ & Heterotroph $^{e}$ & $\begin{array}{l}\text { Ye } \\
\mathrm{s}\end{array}$ & No & No & Yes & $37-50$ & $\begin{array}{l}\text { Facultativ } \\
\mathrm{e}\end{array}$ & N/A \\
\hline
\end{tabular}




\begin{tabular}{|c|c|c|c|c|c|c|c|c|}
\hline $\begin{array}{l}\text { Ferrithrix } \\
\text { thermotolerans }\end{array}$ & Heterotroph $^{\mathrm{e}}$ & $\begin{array}{l}\text { Ye } \\
s\end{array}$ & No & No & Yes & $37-50$ & $\begin{array}{l}\text { Facultativ } \\
\text { e } \\
\text { anaerobe }\end{array}$ & $\mathrm{N} / \mathrm{A}$ \\
\hline $\begin{array}{l}\text { Ferroplasma } \\
\text { acidarmanus }\end{array}$ & Mixotroph $^{c}$ & $\begin{array}{l}\text { Ye } \\
\mathrm{s}\end{array}$ & No & No & Yes & $23-46$ & $\begin{array}{l}\text { Facultativ } \\
\text { e } \\
\text { anaerobe }\end{array}$ & Complete \\
\hline $\begin{array}{l}\text { Ferroplasma } \\
\text { acidiphilum }\end{array}$ & $\begin{array}{l}\text { Chemolithoautotrop } \\
\mathrm{h}^{\mathrm{a}}\end{array}$ & $\begin{array}{l}Y e \\
s\end{array}$ & No & No & No & $15-45$ & Aerobe & $\mathrm{N} / \mathrm{A}$ \\
\hline $\begin{array}{l}\text { Ferrovum } \\
\text { myxofaciens }\end{array}$ & $\begin{array}{l}\text { Chemolithoautotrop } \\
\mathrm{h}^{\mathrm{a}} \\
\text { Diazotroph }^{\mathrm{b}}\end{array}$ & $\begin{array}{l}\text { Ye } \\
\mathrm{s}\end{array}$ & No & No & No & $5-30$ & Aerobe & Contig \\
\hline $\begin{array}{l}\text { Leptospirillum } \\
\text { ferriphilum }\end{array}$ & $\begin{array}{l}\text { Chemolithoautotrop } \\
\mathrm{h}^{\mathrm{a}}\end{array}$ & $\begin{array}{l}\text { Ye } \\
\mathrm{s}\end{array}$ & No & No & No & $25-45$ & Aerobe & Complete \\
\hline $\begin{array}{l}\text { Leptospirillum } \\
\text { ferrodiazotrophu } \\
m\end{array}$ & $\begin{array}{l}\text { Chemolithoautotrop } \\
\mathrm{h}^{\mathrm{a}} \\
\text { Diazotroph }^{\mathrm{b}}\end{array}$ & $\begin{array}{l}\text { Ye } \\
\mathrm{s}\end{array}$ & No & No & No & $37-42$ & Aerobe & $N / A$ \\
\hline $\begin{array}{l}\text { Leptospirillum } \\
\text { ferrooxidans }\end{array}$ & $\begin{array}{l}\text { Chemolithoautotrop } \\
\mathrm{h}^{\mathrm{a}} \\
\text { Diazotroph }^{\mathrm{b}}\end{array}$ & $\begin{array}{l}\text { Ye } \\
\mathrm{s}\end{array}$ & No & No & No & $22-35$ & Aerobe & Complete \\
\hline $\begin{array}{l}\text { Sulfobacillus } \\
\text { acidophilus }\end{array}$ & Mixotroph $^{c}$ & $\begin{array}{l}\text { Ye } \\
\mathrm{s}\end{array}$ & $\begin{array}{l}\text { Ye } \\
\mathrm{s}\end{array}$ & No & Yes & $28-62$ & $\begin{array}{l}\text { Facultativ } \\
\text { e } \\
\text { anaerobe }\end{array}$ & Complete \\
\hline $\begin{array}{l}\text { Sulfobacillus } \\
\text { benefaciens }\end{array}$ & $\begin{array}{l}\text { Facultative } \\
\text { Autotroph }^{\text {h }} \\
\text { Mixotroph }^{\text {c }}\end{array}$ & $\begin{array}{l}\text { Ye } \\
\mathrm{s}\end{array}$ & $\begin{array}{l}\text { Ye } \\
\mathrm{s}\end{array}$ & Yes & Yes & $30-47$ & $\begin{array}{l}\text { Facultativ } \\
\mathrm{e} \\
\text { anaerobe }\end{array}$ & N/A \\
\hline $\begin{array}{l}\text { Sulfobacillus } \\
\text { sibiricus }\end{array}$ & Mixotroph $^{c}$ & $\begin{array}{l}\text { Ye } \\
\mathrm{s}\end{array}$ & No & No & No & $30-55$ & Aerobe & N/A \\
\hline $\begin{array}{l}\text { Sulfobacillus } \\
\text { thermotolerans }\end{array}$ & Mixotroph $^{c}$ & $\begin{array}{l}\text { Ye } \\
\mathrm{s}\end{array}$ & $\begin{array}{l}\mathrm{Ye} \\
\mathrm{s}\end{array}$ & Yes & No & $20-60$ & Aerobe & $\mathrm{N} / \mathrm{A}$ \\
\hline \multicolumn{9}{|c|}{$\begin{array}{l}\text { Adapted from Panda et al. [9] with modifications. } \\
\text { a Chemolithoautotroph = Obtains energy by breaking down chemicals and carbon dioxide }\left(\mathrm{CO}_{2}\right) \text { as carbon } \\
\text { source } \\
{ }^{b} \text { Diazotroph = Able to fix nitrogen }\left(\mathrm{N}_{2}\right) \text { from the atmosphere } \\
{ }^{c} \text { Mixotroph = Obtains energy and carbon source by heterotrophic and autotrophic metabolisms } \\
\text { d } \mathrm{DIRB}=\text { Dissimilatory iron reducing bacteria } \\
\text { e } \\
\text { Heterotroph = Unable to fix carbon dioxide }\left(\mathrm{CO}_{2}\right) \text { and must use organic carbon as carbon source } \\
{ }^{\mathrm{g}} \text { Chemoorganotroph = Obtain energy and carbon source from organic carbon } \\
\text { } \text { AAPB = Aerobic Anoxygenic Photosynthetic Bacteria } \\
\text { h Autotroph = Uses } \mathrm{CO}_{2} \text { as carbon source and produces organic substances } \\
\text { i RISC = Reduced inorganic sulfur compounds } \\
{ }^{*} \text { AAPB is stated to be present within all Acidiphilium species [60] }\end{array}$} \\
\hline
\end{tabular}

While indigenous mesophilic $\left(20-45^{\circ} \mathrm{C}\right)$ and moderate thermophilic $\left(45-60^{\circ} \mathrm{C}\right)$ mining microbes are efficient in leaching metals, increasing temperature can escalate overall reaction kinetics. Extremely thermophilic archaea, which thrive at temperatures higher than $60{ }^{\circ} \mathrm{C}$, have been reported to enhance leaching even further [46]. The rate of 
metal sulfide oxidation is higher in case of the thermoacidophiles as compared to mesoacidophiles. The use of thermophilic archaea cultures is limited due to the fact that these microorganisms are not naturally occurring in mine sites and optimum temperatures can be hard to achieve in the field. Thermophilic heap bioleaching can be a faster alternative for chalcopyrite processing only if the required temperatures for growth and activity of these organisms can be achieved. Some of the other limiting factor of these organisms include lower metal tolerance and greater cell wall sensitivity to higher pulp densities [9]. However, BHP Billiton has succeeded in the commissioning of an aerated stirred-tank reactor using archaea of the genera Acidianus, Metallosphaera, and Sulfolobus. The tank operated at $78{ }^{\circ} \mathrm{C}$ with a pulp density of $12 \%$ (w/w) and recovered 98\% copper from a chalcopyrite concentrate [48].

\section{Recent Advances in Synthetic Biology}

There has been a good deal of recent effort aimed at engineering biomining associated microbes [11-23] and understanding their unique physiology relevant for biomining operations, and more recently for developing new bioenergy applications $[11,49,50]$. Developing genetic tools and synthetic biology techniques for biomining microbes has been challenging because only a limited number of selection markers, plasmids and gene transfer techniques are suitable for these extremophilic organisms [8]. A major reason is their unique growth conditions, involving low $\mathrm{pH}$ and high concentrations of metal ions. These bacteria in general have high restriction barriers to foreign DNA entry and thus a limited number of gene transfer techniques have been developed $[3,50]$. In the case of $A$. ferrooxidans, $A$. thiooxidans and $A$. caldus, gene transfer based on 
conjugation with $E$. coli has been successfully demonstrated [14,19,21-23]. More recently, electroporation has been developed in A. caldus [17] with high transformation efficiencies ( $3.6 \times 10^{4}$ transformants per $\mu \mathrm{g}$ of plasmid DNA) and this has been used to introduce genetic modifications [18]. Genetic engineering techniques have not been reported for Leptospirillum although some of their genes related to arsenic resistance [51] and nickel resistance [52,53] have been cloned and expressed in E. coli.

Plasmids of IncQ, IncP and IncW groups have been shown to function in some of the Acidithiobacillus species [14,21], the IncQ plasmids being the most stable and having the highest conjugative transfer efficiencies [12]. Gene knockout techniques based on homologous recombination have also been shown to generate new strains of $A$. ferrooxidans $[13,15,16], A$. thiooxidans [23] and $A$. caldus [20]. A recent model-driven study of genes in A. ferrooxidans suggested that an increase in extracellular polymer substances (EPS) could be achieved by introducing several genetic knock downs [54]. EPS is important in bioleaching applications as it facilitates bacterial adhesion to the sulfide minerals [54]. Other gene disruption studies and subsequent responses to various metal ions have been reported for Metallosphaera sedula and development of a more characterized genetic system is underway [55].

Another interesting example of genetic engineering in $A$. thiooxidans was the heterologous expression of $E$. coli phosphofructokinase-l or pfkA gene in these organisms [22]. Phosphofructokinase is a key enzyme in glucose metabolism and introduction of this gene significantly stimulated cell growth in the presence of glucose which is otherwise lacking in this chemolithoautotrophic bacteria. In a related approach, the presence of a potential phosphofructokinase-2 gene $(p f K B)$ gene was predicted in 
the A. ferrooxidans strain ATCC 23270 genome. In order to elucidate the role of the pfkb gene, a mutant strain of $A$. ferrooxidans was constructed by knocking out this gene using a markerless gene replacement technique exploiting the homing endonuclease ISce-1 [15]. Interestingly, the mutant strains showed reduced growth in sulfur media compared to wild type cells. Further studies showed that the growth of both wild type and mutant strains could be stimulated by adding glucose in the sulfur media but the extent of stimulation was much lower for the mutant. Overall, only limited glucose utilization was observed in both the cases.

More recently, the expression of green fluorescent protein (GFP) as well as two heterologous biosynthetic metabolic pathways have been reported in A. ferrooxidans. These pathways enable the production of either isobutyric acid or heptadecane $[11,56]$. These pathways were expressed by inserting codon-optimized genes into the pJRD215 (IncQ group) plasmid backbone which was delivered into $A$. ferrooxidans by conjugation with transformed E. coli cells [11]. For production of isobutyric acid, a 2-keto decarboxylase from $L$. lactis was used. For heptadecane production, genes from $S$. elongatus encoding acyl-ACP reductase and aldehyde deformylating oxygenase were used. This is the first report of the metabolic engineering of $A$. ferrooxidans to produce exogenous biochemicals from $\mathrm{CO}_{2}$ using energy obtained from the oxidation of iron. Now efforts are underway to expand the genetic toolbox available for the engineering of A. ferrooxidans. New sulfur-responsive promoters to drive inducible gene expression in A. ferrooxidans have been characterized [57]. And recently, Yu et al. [16] constructed a new strain of $A$. ferrooxidans by knocking out the gene tetrathionate hydrolase (tetH). The tetH knockout mutants lost the ability to grow on tetrathionate $\left(\mathrm{S}_{4} \mathrm{O}_{6}{ }^{2-}\right)$ as an energy 
source. This approach could be used as a new selection strategy for these acidophilic bacteria given the limitations of antibiotic selections due to their unique growth conditions.

The challenges and recent advances made in engineering other chemolithoautotrophic hosts (not involved in biomining applications) as production platforms for useful compounds have also been reviewed in detail [1,3]. A Ralstonia, Rhodobacter and Clostridium, are some of the major non-metal oxidizing chemolithoautotrophic bacteria that have been engineered to produce fuels and other useful chemicals from $\mathrm{CO}_{2}$ $[3,4,50,55,58]$. Microbial electrosynthesis has also been developed in which electroactive bacteria capable of accepting electrons directly and fixing $\mathrm{CO}_{2}$ have been used to produce useful compounds. Detailed discussions on this are beyond the scope of this review and can be found elsewhere [49,50]. A list of some of the useful compounds generated by some genetically modified chemolithoautotrophs are provided in Table 4.

Table 4. List of compounds generated by genetically modified chemolithoautotrophs.

\begin{tabular}{|c|c|c|c|c|c|}
\hline Organism & $\begin{array}{l}\text { Compound } \\
\text { Produced }\end{array}$ & Energy Source & Titers (g/L) & $\begin{array}{c}\text { Batch/Continuo } \\
\text { us }\end{array}$ & $\begin{array}{c}\text { Referenc } \\
\text { e }\end{array}$ \\
\hline \multirow[t]{4}{*}{ R. eutropha } & Methyl Ketones & Hydrogen & 0.18 & 4 days batch & [61] \\
\hline & Cyanophycin & Hydrogen & $0.13 \pm 0.03^{*}$ & 6 days* batch & [62] \\
\hline & Isobutanol & $\begin{array}{l}\text { Formate from } \\
\text { electricity }\end{array}$ & $0.846 \pm 0.05^{*}$ & 6 days batch & {$[6]$} \\
\hline & $\begin{array}{l}\text { 3-methyl-1- } \\
\text { butanol }\end{array}$ & $\begin{array}{c}\text { Formate from } \\
\text { electricity }\end{array}$ & $0.570 \pm 0.05^{*}$ & 6 days batch & [6] \\
\hline \multirow[t]{2}{*}{ R. capsulatus } & Botryococcene & Hydrogen & 0.06 & Continuous & [63] \\
\hline & & & 0.11 & 5 days* batch & \\
\hline \multirow[t]{2}{*}{ C. ljungdahlii } & Butyrate & Syngas $\left(\mathrm{CO}_{2} \&\right.$ & $1.24^{*}$ & 15 days* batch & [64] \\
\hline & Butanol & $\left.\mathrm{H}_{2}\right)$ & 0.15 & 6 days ${ }^{*}$ batch & {$[5]$} \\
\hline C. aceticum & Acetone & $\begin{array}{c}\text { Syngas }\left(\mathrm{CO}_{2} \&\right. \\
\left.\mathrm{H}_{2}\right)\end{array}$ & 0.008 & 6 days ${ }^{*}$ batch & {$[4]$} \\
\hline
\end{tabular}



A. woodii
Acetate
A.
ferrooxidans
Isobutyric acid
$\mathrm{H}_{2}$ )
$\mathrm{Fe}(\mathrm{II})$
Syngas $\left(\mathrm{CO}_{2}\right.$ \&
50
4 days batch
continuous
3 days batch
0.00035
$0.0069 \pm 0.0005$
Heptadecane
$\mathrm{Fe}(\mathrm{II})$
$(4.2 \pm 0.9) \times 10^{-6}$
3 days batch

[65]

[11]

[11]

\section{Conclusions and Future Prospects}

The search for new routes for the generation of chemicals and fuels is critical as we transition away from petroleum resources. Energy-rich sulfide materials are as abundant as petroleum in the Earth's crust. These materials could eventually be developed for dual use: as resources for metal recovery and as feedstocks for $\mathrm{CO}_{2}$ fixation into biochemicals and biofuels. Thus, genetically engineered chemolithoautotrophic bacteria could open up a new paradigm for industrial bioproduction (Figure 4). These advances could also be leveraged to improve metal solubilization and recovery.

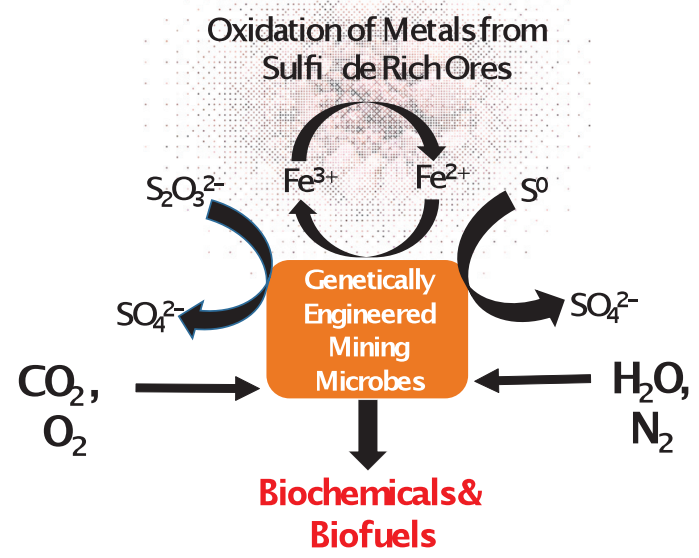


Figure 4. Co-generation of biofuels and other chemicals by genetically modified chemolithoautotrophs during biomining.

Chemolithoautotrophic microorganisms release energy during the oxidation of iron and reduced sulfur compounds during the course of metal mining, most of which is essentially lost into the environment. As shown in Figure 1, the free energy released during oxidation of sulfur is comparable to that released during the combustion of petroleum. Co-generation of fuels from these microorganisms during mining operations can serve as a means of harnessing this virtually untapped terrestrial energy resource. The efficiency of conversion of this energy by the microorganisms and the titers of biochemicals produced are important factors which will impact the commercial feasibility of these co-generation activities. To date, the production of isobutyric acid by genetically engineered $A$. ferrooxidans has only been characterized using $\mathrm{Fe}^{2+}$ as an energy source, and the Gibbs free energy efficiencies for incorporation of this energy into the isoburyric acid product are on the order of $1 \%[11,56,59]$. In order to develop a commercially viable processes, these efficiencies will need to be increased when using mining process streams as feedstocks.

Model autotrophs like Ralstonia and Clostridium, which have emerged as promising candidates for biofuel production, have standard and established genetic modification protocols. On the other hand, metabolic engineering of the biomining organisms has been more difficult due to a lack of established genetic tools and because of their unique growth conditions. However, as advances in this space continue to accelerate, 
more genetic tools will become available for the biomining associated chemolithoautotrophs.

As chemolithautotrophic bioprocesses are developed, new opportunities for their utilization will also arise. For example, there is an increasing interest in the exploration of Mars, and chemolithoautotrophic conversion of $\mathrm{CO}_{2}$ using non-terrestrial minerals may become a critical future technology for these endeavors.

\section{Acknowledgements}

The authors gratefully acknowledge funding through ARPA-E grant DE-AR0000553 from the US Department of Energy. IB, ACW and SB thank Timothy M. Kernan for helpful discussions. BB and CR thank Freeport-McMoRan's Technology Center for support and guidance.

\section{References}

* of special interest

** of outstanding interest

1. Claassens NJ, Sousa DZ, Dos Santos VA, de Vos WM, van der Oost J: Harnessing the power of microbial autotrophy. Nat Rev Microbiol 2016.

* A review that discusses recent advances in engineering autotrophic hosts and explores strategies for engineering improved microbial hosts as autotrophic production platforms

2. Rulli MC, Bellomi D, Cazzoli A, De Carolis G, D'Odorico P: The water-land-food nexus of first-generation biofuels. Sci Rep 2016, 6:22521.

3. Nybo SE, Khan NE, Woolston BM, Curtis WR: Metabolic engineering in chemolithoautotrophic hosts for the production of fuels and chemicals. Metab Eng 2015, 30:105-120.

** A review of challenges and developments in genetic engineering of chemolithoautotrophic bacteria to produce various biofuels and other important compounds.

4. Schiel-Bengelsdorf $B$, Durre $P$ : Pathway engineering and synthetic biology using acetogens. FEBS Lett 2012, 586:2191-2198. 
5. Kopke M, Held C, Hujer S, Liesegang H, Wiezer A, Wollherr A, Ehrenreich A, Liebl W, Gottschalk G, Durre P: Clostridium ljungdahlii represents a microbial production platform based on syngas. PNAS 2010, 107:13087-13092.

6. Li H, Opgenorth PH, Wernick DG, Rogers S, Wu TY, Higashide W, Malati P, Huo YX, Cho $\mathrm{KM}$, Liao JC: Integrated Electromicrobial Conversion of $\mathrm{CO}_{2}$ to Higher Alcohols. Science 2012, 335:1596-1596.

7. Rawlings DE: Heavy metal mining using microbes. Annu Rev Microbiol 2002, 56:65-91.

8. Agate AD: Recent advances in microbial mining. World Journal of Microbiology \& Biotechnology 1996, 12:487-495.

9. Panda S, Akcil A, Pradhan N, Deveci H: Current scenario of chalcopyrite bioleaching: A review on the recent advances to its heap-leach technology. Bioresource Technology 2015, 196:694-706.

* A review describing recent advances and future prospects in microbial bioleaching of chalcopyrite

10. Valdes J, Pedroso I, Quatrini R, Dodson RJ, Tettelin H, Blake R, Eisen JA, Holmes DS: Acidithiobacillus ferrooxidans metabolism: from genome sequence to industrial applications. Bmc Genomics 2008, 9.

11. Kernan T, Majumdar S, Li XZ, Guan JY, West AC, Banta S: Engineering the ironoxidizing chemolithoautotroph Acidithiobacillus ferrooxidans for biochemical production. Biotechnology and Bioengineering 2016, 113:189-197.

** A paper demonstrating the first expression of two heterologous pathways leading to the generation of isobutyric acid or heptadecane in A. ferrooxidans.

12. Liu Z, Borne F, Ratouchniak J, Bonnefoy V: Genetic transfer of IncP, IncQ and IncW plasmids to four Thiobacillus ferrooxidans strains by conjugation. Hydrometallurgy 2001, 59:339-345.

13. Liu ZY, Guiliani N, Appia-Ayme C, Borne F, Ratouchniak J, Bonnefoy V: Construction and characterization of a recA mutant of Thiobacillus ferrooxidans by marker exchange mutagenesis. Journal of Bacteriology 2000, 182:2269-2276.

14. Peng JB, Yan WM, Bao XZ: Plasmid and transposon transfer to Thiobacillus ferrooxidans. Journal of Bacteriology 1994, 176:2892-2897.

15. Wang HY, Liu XM, Liu SS, Yu YY, Lin JQ, Lin JQ, Pang X, Zhao J: Development of a Markerless Gene Replacement System for Acidithiobacillus ferrooxidans and Construction of a pfkB Mutant. Applied and Environmental Microbiology 2012, 78:1826-1835.

16. Yu YY, Liu XM, Wang HY, Li XT, Lin JQ: Construction and Characterization of tetH Overexpression and Knockout Strains of Acidithiobacillus ferrooxidans. Journal of Bacteriology 2014, 196:2255-2264.

* A paper demonstrating the development of a new $A$. ferrooxidans strain which cannot grow on tetrathionate as a sole energy source.

17. Chen LX, Lin JQ, Li B, Lin JQ, Liu XM: Method Development for Electrotransformation of Acidithiobacillus caldus. Journal of Microbiology and Biotechnology 2010, 20:3944.

18. Chen LX, Lin JQ, Liu XM, Pang X, Lin HB, Lin JQ: Transposition of IS elements induced by electroporation of suicide plasmid in Acidithiobacillus caldus. Enzyme and Microbial Technology 2013, 53:165-169.

19. Liu XM, Lin JQ, Zhang Z, Bian J, Zhao Q, Liu Y, Lin JQ, Yan WM: Construction of conjugative gene transfer system between E-coli and moderately thermophilic, 
extremely acidophilic Acidithiobacillus caldus MTH-04. Journal of Microbiology and Biotechnology 2007, 17:162-167.

20. Van Zyl LJ, van Munster JM, Rawlings DE: Construction of arsB and tetH mutants of the sulfur-oxidizing bacterium Acidithiobacillus caldus by marker exchange. Applied and Environmental Microbiology 2008, 74:5686-5694.

21. Jin SM, Yan WM, Wang ZN: Transfer of Incp plasmids to extremely acidophilic Thiobacillus thiooxidans. Applied and Environmental Microbiology 1992, 58:429-430.

22. Tian KL, Lin JQ, Liu XM, Liu Y, Zhang CK, Yan WM: Conversion of an obligate autotrophic bacteria to heterotrophic growth: expression of a heterogeneous phosphofructokinase gene in the chemolithotroph Acidithiobacillus thiooxidans. Biotechnology Letters 2003, 25:749-754.

23. Wen $Q$, Liu XM, Wang HY, Lin JQ: A versatile and efficient markerless gene disruption system for Acidithiobacillus thiooxidans: application for characterizing a copper tolerance related multicopper oxidase gene. Environmental Microbiology 2014, 16:3499-3514.

24. Survey USG: Minerals commodities summaries 2016. U.S. Geological Survey 2016, 202: http://dx.doi.org/10.3133/70140094.

25. Johnson DB: The biogeochemistry of biomining. In Geomicrobiology: Molecular and Environmental Perspectives. Edited by Loy, A, Mandl, M, Barton, L. Springer; 2010:401-426.

26. Schmitz KS: Appendix I. In Physical Chemistry: Concepts and Theory. Elsevier; 2016:99158.

27. Karp G: Bioenergetics, enzymes and metabolism. In Cell and Molecular Biology: Concepts and Experiments. John Wiley \& Sons; 2009:86-119.

28. Johnson DB: Biomining - biotechnologies for extracting and recovering metals from ores and waste materials. Current Opinion in Biotechnology 2014, 30:24-31.

${ }^{* *}$ A paper describing the mechanisms involved in commercial biomining operations, the development of technology over time, and the challenges and prospects for mineral biotechnologies in the $21^{\text {st }}$ century.

29. Brierley CL, Brierley JA: Progress in bioleaching: part B: applications of microbial processes by the minerals industries. Applied Microbiology and Biotechnology 2013, 97:7543-7552.

30. Riekkola-Vanhanen M: Bioheapleaching. Talvivaara Mining company, London: 2010.

31. Olson GJ, Clark TR: Bioleaching of molybdenite. Hydrometallurgy 2008, 93:10-15.

32. Dold B: Sustainability in metal mining: from exploration, over processing to mine waste management. Reviews in Environmental Science and BioTechnology 2008, 7:275-285.

33. Brierley C: Copper heap leach short course: Bioleaching. In Society of Mining Engineers Annual Meeting; Phoenix, Arizona: 2016.

34. Brierley CL: How will biomining be applied in future? Transactions of Nonferrous Metals Society of China 2008, 18:1302-1310.

35. Mineral Resource Surveys Program (U.S.), Geological Survey (U.S.): The Global Mineral Resource Assessment Project. In USGS fact sheet FS-053-03. Edited by. Reston, Va.: U.S. Dept. of the Interior, U.S. Geological Survey; 2003.

36. Meinert LD Robinson Jr GR, Nassar NT: Mineral Resources: Reserves, Peak Production and the Future. Resources 2016, 5: DOI:10.3390/resources5010014

37. Vaughan DJ: Sulfide mineralogy and geochemistry: Introduction and overview. Sulfide Mineralolgy and Geochemistry 2006, 61:1-5.

38. P. G. West-Sells, S.C.B., Tshilombo AF, Bruynesteyn aA: Acid generation by in-situ sulfur biooxidation for copper heap leaching. 2007. 
39. Gericke M: Review of the role of microbiology in the design and operation of heap bioleaching processes. Journal of the Southern African Institute of Mining and Metallurgy 2012, 112:1005-1012.

40. Cordoba EM, Munoz JA, Blazquez ML, Gonzalez F, Ballester A: Leaching of chalcopyrite with ferric ion. Part I: General aspects. Hydrometallurgy 2008, 93:81-87.

41. Pan HD, Yang HY, Tong LL, Zhong CB, Zhao YS: Control method of chalcopyrite passivation in bioleaching. Transactions of Nonferrous Metals Society of China 2012, 22:2255-2260.

42. Schippers A, Sand W: Bacterial Leaching of Metal Sulfides Proceeds by Two Indirect Mechanisms via Thiosulfate or via Polysulfides and Sulfur. Applied And Environmental Microbiology 1999, 65:319-321.

43. Ekenes JM, Caro CA: Improving leaching recovery of copper from low-grade chalcopyrite ores. Minerals \& Metallurgical Processing 2013, 30:180-185.

44. Hawkins A, Han Y, Lian H, Loder A, Menon A, Iwuchukwu I, Keller M, Leuko T, Adams M, Kelly R: Extremely Thermophilic Routes to Microbial Electrofuels. ACS Catalysis 2011, 1:1043-1050.

45. Brune KD, Bayer TS: Engineering microbial consortia to enhance biomining and bioremediation. Frontiers in Microbiology 2012, 3.

46. Wheaton G, Counts J, Mukherjee A, Kruh J, Kelly R: The Confluence of Heavy Metal Biooxidation and Heavy Metal Resistance: Implications for Bioleaching by Extreme Thermoacidophiles. Minerals 2015, 5:397-451.

** A review of thermoacidophilic bacteria and their roles in metal oxidation including biomining operations.

47. Shiers DW, Collinson DM, Watling HR: Life in heaps: a review of microbial responses to variable acidity in sulfide mineral bioleaching heaps for metal extraction. Research in Microbiology 2016, 167:576-586.

48. Brierley JA: A perspective on developments in biohydrometallurgy. Hydrometallurgy 2008, 94:2-7.

49. Lovley DR, Nevin KP: Electrobiocommodities: powering microbial production of fuels and commodity chemicals from carbon dioxide with electricity. Curr Opin Biotechnol 2013, 24:385-390.

50. Sydow A, Krieg T, Mayer F, Schrader J, Holtmann D: Electroactive bacteria-molecular mechanisms and genetic tools. Applied Microbiology and Biotechnology 2014, 98:8481-8495.

51. Li B, Lin J, Mi S, Lin J: Arsenic resistance operon structure in Leptospirillum ferriphilum and proteomic response to arsenic stress. Bioresource Technology 2010, 101:9811-9814.

52. Tian J, Wu NF, Li J, Liu YJ, Guo J, Yao B, Fan YL: Nickel-resistant determinant from Leptospirillum ferriphilum. Applied and Environmental Microbiology 2007, 73:23642368.

53. Zhu T, Tian J, Zhang S, Wu N, Fan Y: Identification of the Transcriptional Regulator NcrB in the Nickel Resistance Determinant of Leptospirillum ferriphilum UBK03. Plos One 2011, 6.

54. Miguel A. Campodonico DV, Jean F. Castro, Valeria Razmilic, Francesca Mercado, Barbara A. Andrews, Adam M. Feist, Juan A. Asenjo: Acidithiobacillus ferrooxidans's comprehensive model driven analysis of the electron transfer metabolism and synthetic strain design for biomining applications. Metabolic Engineering Communications 2016, 3:84-96. 
55. Hawkins AS, McTernan PM, Lian H, Kelly RM, Adams MWW: Biological conversion of carbon dioxide and hydrogen into liquid fuels and industrial chemicals. Current Opinion in Biotechnology 2013, 24:376-384.

56. Li XZ, West AC, Banta S: Enhancing isobutyric acid production from engineered Acidithiobacillus ferrooxidans cells via media optimization. Biotechnology and Bioengineering 2016, 113:790-796.

57. Kernan T, West, A.C., and Banta, S. : Characterization of endogenous promoters for control of recombinant gene expression in A. ferrooxidans. Biotechnology and Applied Biochemistry 2017.

58. Nevin KP, Woodard TL, Franks AE, Summers ZM, Lovley DR: Microbial electrosynthesis: feeding microbes electricity to convert carbon dioxide and water to multicarbon extracellular organic compounds. MBio 2010, 1.

59. Guan J, Berlinger SA, Li X, Chao Z, Sousa E Silva V, Banta S, West AC: Development of reactor configurations for an electrofuels platform utilizing genetically modified iron oxidizing bacteria for the reduction of $\mathrm{CO}_{2}$ to biochemical. Journal of Biotechnology 2017, 245:21-27.

60. Hiraishi A, Shimada K: Aerobic anoxygenic photosynthetic bacteria with zincbacteriochlorophyll. Journal of General and Applied Microbiology 2001, 47:161-180.

61. Mueller J, MacEachran D, Burd H, Sathitsuksanoh N, Bi C, Yeh Y-C, Lee TS, Hillson NJ, Chhabra SR, Singer SW, et al.: Engineering of Ralstonia eutropha H16 for Autotrophic and Heterotrophic Production of Methyl Ketones. Applied and Environmental Microbiology 2013, 79:4433-4439.

62. Luette S, Pohlmann A, Zaychikov E, Schwartz E, Becher JR, Heumann H, Friedrich B: Autotrophic Production of Stable-Isotope-Labeled Arginine in Ralstonia eutropha Strain H16. Applied and Environmental Microbiology 2012, 78:7884-7890.

63. Khan NE, Nybo SE, Chappell J, Curtis WR: Triterpene hydrocarbon production engineered into a metabolically versatile host $R$ hodobacter capsulatus. Biotechnology and Bioengineering 2015, 112:1523-1532.

64. Ueki T, Nevin KP, Woodard TL, Lovley DR: Converting Carbon Dioxide to Butyrate with an Engineered Strain of Clostridium Ijungdahlii. Mbio 2014, 5.

65. Straub M, Demler M, Weuster-Botz D, Durre P: Selective enhancement of autotrophic acetate production with genetically modified Acetobacterium woodii. Journal of Biotechnology 2014, 178:67-72. 